\title{
Chul-Gyoo Park, M.D., Ph.D., 1942 to 2020
}

\section{Hak Chang}

Department of Plastic and Reconstructive Surgery, Research Institute of Plastic and Reconstructive Surgery (RIPRS), Seoul National University College of Medicine, Seoul, Korea

Professor Chul-Gyoo Park was a great surgeon, as well as a beloved father and teacher, with innumerable achievements. On January 22, 2020, he passed away in a tragic accident and we lost one of our greatest plastic surgeons.

Professor Park was one of the pioneers of plastic surgery in Korea. He was born in Buyeo in 1942. After graduating from Seoul National University College of Medicine in 1967, he became a general surgeon at Seoul National University Hospital. He finished his residency in general surgery in 1972. After completing his military service, he started as an instructor of general surgery at Seoul National University College of Medicine in 1976. At that time, he changed his specialization to plastic surgery and obtained a professional qualification as a plastic surgeon in 1978.

He started his professorship in 1978, and served as the department chair from 1992 to 1998. He was a key player in making Korean plastic surgery internationally renowned, through his service as the second President of the Korean Cleft Palate-Craniofacial Association (1995-1997), the 22nd President of the Korean Society of Plastic and Reconstructive Surgeons (2000-2002), and the President of the Asian Pacific Craniofacial Association (2000-2002). After his retirement in 2008, he embarked upon a second professorship at Ilsan Paik Hospital and National Medical Center.

As mentioned earlier, Professor Park was both a general surgeon and a plastic surgeon. He combined a general surgeon's mind with a plastic surgeon's skills. This blended skillset has been of tremendous value for teaching his numerous disciples, especially in the field of craniofacial surgery. His bold surgical skills and aggressively inventive mindset in the days when we did not have access to advanced equipment like today served as a basis for his disciples to subsequently become masters of bone surgery. In addition to patients who needed craniofacial surgery, he performed surgery on many pediatric patients with cleft lip and palate or congenital melanocytic nevus. He was one of the most experienced plastic surgeons with the use of tissue expanders for congenital nevus.

$\mathrm{He}$ also did a great job as a father. Both of his sons are alumni and plastic surgeons. He always liked to invite his juniors and trainees to events at his home. He was sometimes tough, but he always taught his students like a loving father. Professor Park influenced

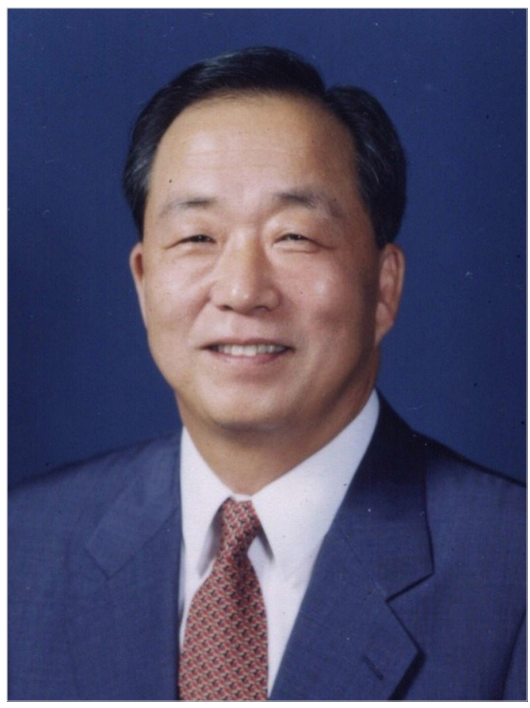

Chul-Gyoo Park, M.D., Ph.D. 
not only his family, but also the following generations of doctors and plastic surgeons in Korea. The life of Professor Park as a doctor, father, and an individual was truly honorable. May he rest in peace.

\section{Notes}

\section{Conflict of interest}

No potential conflict of interest relevant to this article was reported.

\section{ORCID}

Hak Chang

\section{Correspondence: Hak Chang}

Department of Plastic and Reconstructive Surgery, Seoul National University College of Medicine, 101 Daehak-ro, Jongno-gu, Seoul 03080, Korea

Tel: +82-2-2072-3086, Fax: +82-2-747-5130, E-mail: prshchang@gmail.com

Received: July 10, $2020 \bullet$ Revised: July 10, $2020 \bullet$ Accepted: July 10, 2020

pISSN: 2234-6163・ elSSN: 2234-6171

https://doi.org/10.5999/aps.2020.01417 • Arch Plast Surg 2020;47:375-376 